\title{
Delme Hızının Akışkan Ortam Basıncı ve Dönme Hızına Bağlı Değişiminin Araştırılması
}

\author{
İksan TUNCER*1, Raşit ALTINDAĞ ${ }^{2}$ \\ ${ }^{1}$ DSİ 18. Bölge Müdürlüğ̈̈, Emlak ve Kamulaștırma Şube Müdürlüğü, 32200, Isparta \\ ${ }_{1}^{1}$ (ORCID:https://orcid.org/0000-0001-7627-9907) \\ ${ }^{2}$ Süleyman Demirel Üniversitesi, Mühendislik Fakültesi, Maden Mühendisliği Bölümü, 32260, Isparta \\ ${ }^{2}$ (ORCID:https://orcid.org/0000-0002-5397-7312)
}

(Alınıș / Received: 18.04.2018, Kabul / Accepted: 19.12.2018, Online Yayınlanma / Published Online: 06.03.2019)

\section{Anahtar Kelimeler}

Delme hızl,

Delinebilirlik,

Kireçtaşı

\begin{abstract}
Özet: Bir maden işletmesinde maliyet teşkil eden parametrelerin başında hammadde temini gelmektedir. Hammadde üretim maliyetlerinin en önemli parametrelerinden biri de patlatma deliklerinin delinmesi işidir. Delme işlemlerinde istenen verimde çalışılmaması durumunda hem işletmede iş organizasyonu hem de üretim maliyeti önemli ölçüde olumsuz yönde etkilenecektir. Bu çalışmasında DSİ 18. Bölge Müdürlüğü'ne ait kireçtaşı ocağında kullanılan Atlas Copco Flexi ROC T35 model delici makineye ait akışkan ortam basıncı ve dönme hızı parametrelerinin değiștirilmesi sonucunda delik delme verimlerine etkisi incelenmiştir. Delik delme hızının belirlenmesi amacıyla Burdur ili, Çavdır ilçesinde bulunan kireçtaşı ocağında çalışılan ortamdaki delik delme süreleri ölçülmüș ve net ve brüt delik delme hızları hesaplanmıştır. Laboratuvar ortamında da kayaçların fiziko-mekanik özellikleri ile kimyasal özellikleri belirlenmiştir. Elde edilen bütün veriler birlikte değerlendirilerek akışkan ortam basıncı ve dönme hızının delme hızı üzerindeki etkileri incelenmiştir. Sonuç olarak tüm akışkan ortam basınç değerlerinde ve her iki dönme hızında en iyi delik delme hızı 103 rpm dönme hızı değerinde elde edilmiştir.
\end{abstract}

\section{Investigation of Change in Drilling Speed Depending on Fluid Ambient Pressure and Rotation Speed}

\section{Keywords}

Drilling speed, Drillability,

Limestone

\begin{abstract}
One of the most costly parameters in a mining operation is the raw material procurment. One of the most important parameters of raw material procurment cost is the drilling of blasting holes. If the drilling operations are not performed at the desired efficiency, both the working organization in business and the production cost will be significantly and adversely affected in the negative direction. In this study, the effect of drilling parameters on the fluid ambient pressure and rotational speed parameters of the Atlas Copco Flexi ROC T35 drilling machine used in the limestone quarry of DSI 18th Regional Directorate was investigated. In order to determine the drilling speed, the drilling times of the working limestone in the limestone oven at Çavdır county in Burdur province were measured and clear and gross drilling speeds were calculated. The physicomechanical properties and chemical properties of the rocks were also determined in the laboratory environment. By evaluating all the data together, effect of fluid ambient pressure and rotating speed on drilling speed are examined. As a result, the best drilling speed at all fluid ambient pressure and at both rotational speeds was obtained at a rotational speed of $103 \mathrm{rpm}$.
\end{abstract}

\section{Giriş}

Kayaçlarda delme işlemi, madencilik ve inşaat sektöründe birçok amaçla kullanılmaktadır. Delme işlemleri, madencilik sektöründe patlatma işleminin gerçekleştirileceği deliklerin delinmesi için yapılmaktadır. Delme işleminin zorluğu veya kolaylığı kayacın delinmeye karşı gösterdiği dirence bağlıdır. $\mathrm{Bu}$ direnç kayaçların fizikomekanik özelliklerinin yanında delinen ortamın jeoteknik özelliklerine ve çalışma parametrelerine göre de değişkenlik göstermektedir. Ayrıca kayaçların delinebilirliğinde kayacın dokusu, kuvars içeriği, mineral tane boyutu gibi mineralojik ve petragrofik özellikleri de etkilidir. 
Ocak işletmelerinde maliyeti artıran en önemli parametre hammadde temini için hazırlık ve kazı işlemleridir. Hammadde üretim işlemlerinden delme, patlatma ve nakliye içerisinden maliyetlerin artmasına etken en önemli işlem patlatma deliklerinin delinmesidir. [1]

Cankurtaran ve Salmankaş tünellerindeki kayaçların delinebilirlik, aşındırıcılık, mekanik ve petrografik özelliklerinin araştırılması, net delme hızı ve bit tüketimi ile ilişkilendirilmesi çalışmalarında tünel güzergahı üzerindeki kazılan formasyonlardan numuneler kullanmıșdır. Kayaçların mekanik özellikleri (Tek eksenli basınç dayanımı, Nokta yük dayanımı, Brazilian çekme dayanımı ) ve görünür porozite ile delinebilirlik indeksi arasındaki ilişkiler ortaya konulmuştur. Tek eksenli basınç dayanımı $(\mathrm{r}=0.85)$, Nokta yük dayanımı $(\mathrm{r}=0.85)$, Brazilian çekme dayanımı ( $\mathrm{r}=0.77)$, görünür porozite ( $\mathrm{r}=0.72)$ ile delinebilirlik indeksi arasında anlamlı bir ilişki olduğu saptanmıştır. Kayaçların mekanik özellikleri (Tek eksenli basınç dayanımı, Nokta yük dayanımı, Brazilian çekme dayanımı ) ve görünür porozite ile bit ömrü ile arasındaki ilişkiler ortaya konulmuştur. Tek eksenli basınç dayanımı ( $r=0.73)$, Nokta yük dayanımı ( $\mathrm{r}=0.63)$, Brazilian çekme dayanımı $(r=0.65)$, bit ömrü ile arasında anlamlı bir ilişki olduğu saptanmıştır. Delinebilirlik indeksi ile bit ömrü arasındaki ise ( $r=0.63)$ korelasyon değeri ile anlamlı bir ilişki olduğu belirlenmiştir [2].

Delinebilirlik indeksi ile kayaç özellikleri arasındaki ilişkileri 32 farklı numune için belirlemiştirler (kuvarsit, kireçtaşı, diyabaz, granodiorit, litik arenit, kumtaşı, siyenit, dolomit, porfirik bazalt ve andezit, bazaltik andezit, dolorit, alkali granit, bazalt, andesitik bazalt, traki andezit, dolomitik kireçtaşı, granit, marn). Kayaçların mekanik özellikleri (Schmidt çekiçi sertliği, Brazilian çekme dayanımı, Tek eksenli basınç dayanımı, Shore sertliği ve Nokta yük dayanımı) ile delinebilirlik indeksi arasındaki ilişkiler ortaya konulmuştur. Tek eksenli basınç dayanımı $(r=0,71)$, Schmidt çekiçi sertliği $(r=0,78)$, Nokta yük dayanımı $(r=0,71)$, Shore sertliği $(r=0,64)$ ile delinebilirlik indeksi arasında anlamlı bir ilişki olduğu belirlenmiştir. Brazilian çekme dayanımı $(\mathrm{r}=0,55)$ ile de delinebilirlik indeksi arasında bir ilişki olduğu saptanmıştır [3].

Açık ocaklarda kaya kütlesi delme indeksi (RMDI) değerlerinden delme hızı tahmin edilebilmesini çalışmalarının amacı olmuştur. Çalışmalarında Manyetit ve yan kayaç numunelerini kullanmışlardır. Kayaçların mekanik özellikleri (Schmidt çekiçi sertliği, Elastisite modülü, Brazilian çekme dayanımı, Tek eksenli basınç dayanımı, $P$ dalgası sismik hız, $S$ dalgası sismik hız) ve Porozite ile delme hızı rasındaki ilişkiler ortaya konulmuştur. Brazilian çekme dayanımı $(\mathrm{r}=0,79)$, Tek eksenli basınç dayanımı $(\mathrm{r}=0,87)$ ve Schmidt çekiçi sertliği $(\mathrm{r}=0,89)$ $P$ dalgası sismik hız $(\mathrm{r}=0,79), S$ dalgası sismik hız $(r=0,73)$, porozite $(r=0,70)$ ile delme hızı arasında anlaml bir ilişki olduğu belirlenmiştir. Elastisite modülü $(r=0,44)$ ile de delme hızı arasında azda olsa bir ilişki olduğu saptanmıştır [4].

Bu çalışma kapsamında DSİ 18. Bölge Müdürlügü’nün Burdur ili, Çavdır ilçesinde yapımı gerçekleştirilen Küçükalan Göleti ve Sulaması inşaatı Kireçtaşı ocağında çalışmalar gerçekleștirilmiştir. Ocak sahasında gerçekleştirilen patlatma deliği delme hızının delici makine çalışma parametrelerinden olan akışkan ortam basıncı ve dönme hızı değerlerinin değişiminden nasıl etkilendiği araştırılmıştır. Elde edilen verilerden delme verimi ortaya konulmuştur.

\section{Materyal ve Metot}

\subsection{Materyal}

Çalışmada Burdur ili, Çavdır ilçesinde inşaatı tamamlanan Küçükalan Göleti ve Sulaması İnşaatı kireçtaşı ocağında gerçekleştirilmiştir. Ocak sahasında gerçekleştirilen patlatma deliği delme işlemlerinde akışkan ortam basıncı ve dönme hızının, delme hızı üzerindeki etkisi araştırılmıștır.

Çalıșılan ocak sahasının yer buldurur haritası Şekil 1'de verilmiştir.

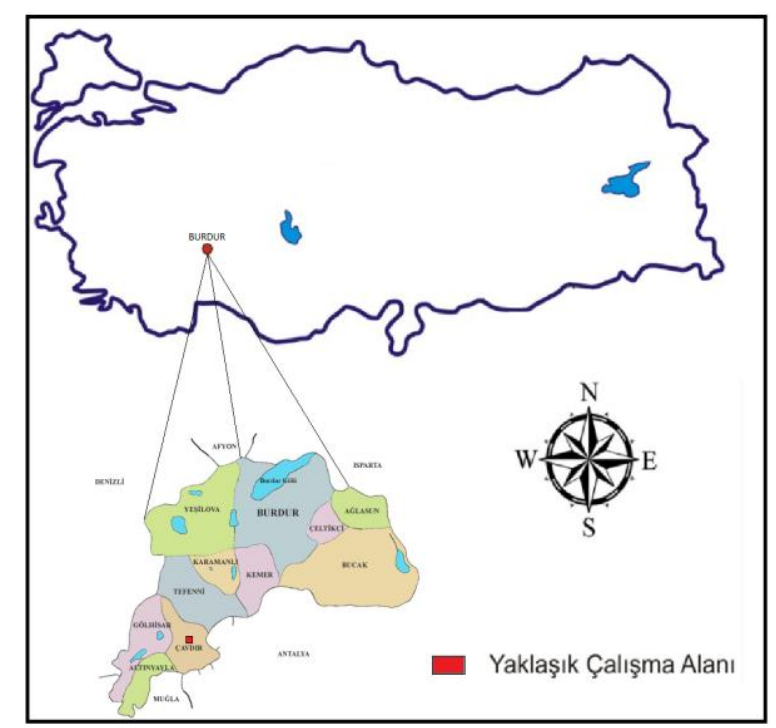

Şekil 1. Ocak sahasının yer buldurur haritası [5]

Ocak sahası içerisinde iki farklı formasyon olmasından dolayı ve bu iki formasyonda da delme işlemi gerçekleştirildiğinden delme işlemi gerçekleştirilen lokasyonun birine 1 nolu ocak sahası diğerine ise 2 nolu ocak sahası denilmiştir. Bir ve iki nolu ocak sahalarının genel görünümü Şekil 2'de verilmiştir.

\subsubsection{Delici makine}

Ocak sahasındaki delik delme işlerinde Atlas COPCO Flexi ROC T35 delici ekipman (Şekil 3) kullanılmıştır. 


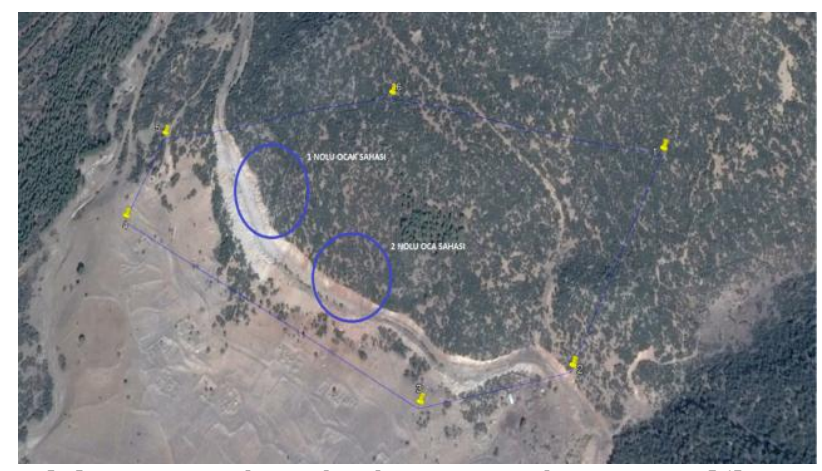

Şekil 2. 1 ve 2 nolu ocak sahasının genel görünümü [5]

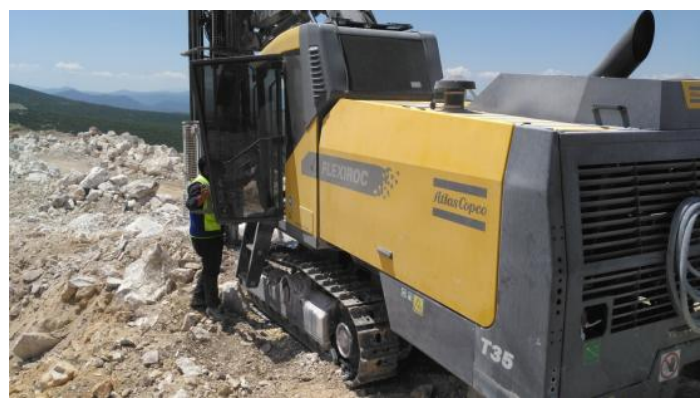

Şekil 3. Atlas Copco Flexi ROC T35 delici makine [6]

Çalışma sahasında gerçekleştirilen delik delme işlemlerinde Atlas Copco'ya ait 89 mm çapl, 5 kanallı, düz dolaşıml, yarı balistik butonlu, merkezden girintili drop center (DC) delici uç kullanılmıştır (Şekil 4).

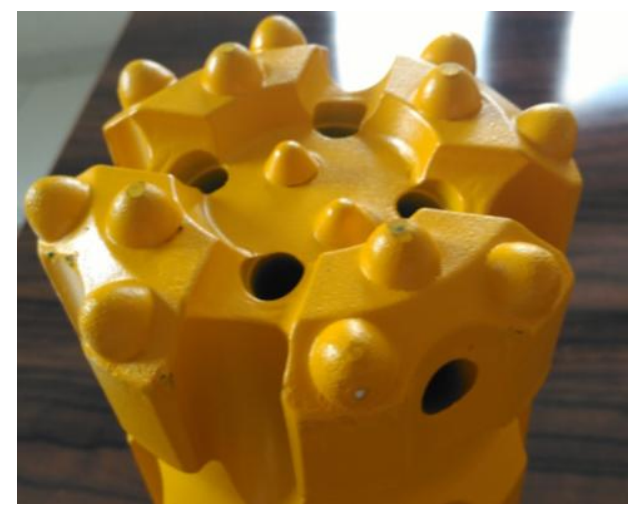

Şekil 4. Çalıșmada kullanılan delici uç [6]

\subsection{Metod}

Delinebilirlik; bir matkabın kayaç içinde belirli bir zamanda kayacı delerek ilerlemesidir. Bir diğer ifade ile kaya kütlesinde delik delme kolaylığıdır. Delme hızı ise kayaç içerisinde, $\mathrm{m} / \mathrm{dk}, \mathrm{cm} / \mathrm{dk}$ veya $\mathrm{mm} / \mathrm{dk}$ olarak ölçülür. Delinebilirlik ile delme hızı aynı kavram olarak tanımlanabilir. Delinebilirlik kolay ya da zor olarak delme hızı ise hızlı ya da yavaş olarak ifade edilir. Delinebilirliğe etki eden birçok parametre vardır. Bunlar; makine ekipmana bağlı parametreler (dönme hızı, baskı kuvveti, matkap tipi v.b.), delme işlemine bağlı parametreler (delme yöntemi, makinanın çalışma performansı ve bakımı, sondörün deneyimi v.b.) ile jeolojik parametrelerdir (kayaçların mekanik özellikleri, süreksizlikler, mineral bileşimi). Makine, ekipman ve delme işlemine bağlı parametreler kontrol edilebilir parametreler olup, jeolojik özelliklere bağlı parametreler ise kontrol edilemeyen parametrelerdir [7]. Delinebilirliğe etki eden parametreler Şekil 5'te verilmiştir.

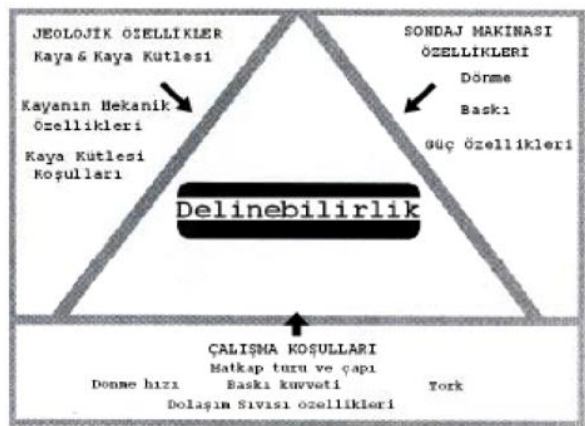

Şekil 5. Delinebilirliğe etki eden parametreler [8]

Çalışmada, delme işlemleri esnasında bir basamakta gerçekleştirilen delik delme işlemlerinin yarısı akışkan ortam basıncı 5 bar ve dönme hızı 107 rpm iken gerçekleştirilmiş, aynı basamaktaki kalan delikler ise akışkan ortam basıncı 5 bar ve dönme hızı 103 rpm olacak şekilde gerçekleştirilmiştir. Diğer basamakta gerçekleştirilen delik delme işlemlerinin yarısı akışkan ortam basıncı 7 bar ve dönme hızı 107 rpm olarak gerçekleştirilmiş, aynı basamaktaki kalan delikler ise akışkan ortam basıncı 7 bar ve dönme hızı 103 rpm olacak şekilde gerçekleştirilmiştir. Diğer basamakta gerçekleştirilen delik delme işlemlerinin yarısı akışkan ortam basıncı 9 bar ve dönme hızı 107 rpm olarak gerçekleştirilmiş, aynı basamaktaki kalan delikler ise akışkan ortam basıncı 9 bar ve dönme hızı 103 rpm olacak şekilde gerçekleştirilmiştir.

\subsubsection{Delme hizı}

Çalışma sahasında 1 nolu ocakta toplam 180 adet ve 2 nolu ocak sahasında 229 adet delik delme işlemi gerçekleştirilmiştir. Her bir delikte delik boyuna göre kullanılan tijlerin ayrı ayrı $\mathrm{PR}_{\mathrm{Net}}(\mathrm{m} / \mathrm{dak})$ ve $\mathrm{PR}_{\text {Brüt }}$ (m/dak) değerleri süreölçer ile tespit edilmiştir. PRBüt, delme işleminin başlangıç zamanı ile bitiş zamanı arasındaki geçen süreyi (toplam süre); PRNet ise sadece delme işlemi için geçen süreyi (net delme süresi) belirtmektedir. İki ayrı zamanın tutulmasının nedeni ise, delik delme sürecinde hem delme işinin yapılması hem de deliğin temizlenmesi ve tij ilave edilmesinden dolayıdır. Brüt ve net delme hızı Eşitlik 1 ve 2 ile hesaplanmıştır.

$$
\begin{aligned}
& P R_{\text {Brüt }}=\frac{H}{T} \\
& P R_{\text {Net }}=\frac{H}{T_{\text {net }}}
\end{aligned}
$$

Burada;

PRBrüt :

$\mathrm{PR}_{\mathrm{Net}}$ :

$\mathrm{T}:$

Tnet :

$\mathrm{H} \quad$ :
Brüt delme hızı, m/dak Net delme hızı, m/dak Toplam delik delme süresi, dakika Net delik delme süresi, dakika Delik boyu, metre 


\subsubsection{Fiziko-mekanik özellikler}

Arazi çalışmaları süresince ocak sahasında ölçüm (delik delme hızı) yapılan noktalardan alınan kayaç örneklerinden laboratuvar ortaminda deney numuneleri hazırlanmış ve ilgili standartlara (ISRM ve TSE) uygun olarak hazırlanan numunelerin fiziksel ve mekanik özellikleri belirlenerek Tablo 1 ve Tablo 2 'de verilmiștir.

Çalışmanın bu aşamasında kireçtaşının fiziksel özelliklerinden, ağırlıkça su emme ve hacimce su emme TSE 13755 (2009) [9], birim hacim ağırlık TSE, yoğunluk, porozite TSE 1936 (2010) [10], mekanik özelliklerinden sismik $\left(V_{p}\right)$ hız Shore sertliği, Schmidt çekici sertliği, Tek eksenli basınç dayanımı, Endirek çekme dayanımı (Brazilian), Nokta yük dayanım indeksi deneyleri ISRM (2007) [11] standartlarında yapılmıștır. Bu deneylerin yapılmasının sebebi şöyle açıklanabilir: kayacın delinebilirliği ile ilgili özelliklerinin tam olarak ortaya konulması aşamasında katkı sağlayacak verilerdir.

Tablo 1. 1 nolu ocak sahasının fiziko-mekanik özellikleri [12]

\begin{tabular}{|c|c|c|c|c|}
\hline & \multicolumn{4}{|c|}{$1 \mathrm{NOLU}$ OCAK } \\
\hline & $\begin{array}{l}\text { Minimum } \\
\text { Değer }\end{array}$ & $\begin{array}{l}\text { Maksimum } \\
\text { Değer }\end{array}$ & $\begin{array}{l}\text { Ort. } \\
\text { Değer }\end{array}$ & $\begin{array}{l}\text { Standart } \\
\text { Sapma }\end{array}$ \\
\hline $\begin{array}{l}\text { Birim Hacim } \\
\text { A } \breve{g}_{\text {Irllk }} \\
\left(\mathrm{d}_{\mathrm{h}}\right),\left(\mathrm{g} / \mathrm{cm}^{3}\right)\end{array}$ & 2.68 & 2.7 & 2.69 & 0.006 \\
\hline $\begin{array}{c}\text { Ağırlıkça } \\
\text { Su } \\
\text { Emme (ASE), (\%) }\end{array}$ & 0.1 & 0.16 & 0.12 & 0.02 \\
\hline $\begin{array}{c}\text { Hacimce } \\
\text { Su } \\
\text { Emme (HSE), (\%) }\end{array}$ & 0.17 & 0.33 & 0.25 & 0.06 \\
\hline $\begin{array}{c}\text { Gerçek } \\
\text { Yoğunluk }\left(\mathrm{d}_{0}\right) \\
\left(\mathrm{kN} / \mathrm{m}^{3}\right)\end{array}$ & 26.51 & 26.61 & 26.55 & 0.06 \\
\hline $\begin{array}{l}\text { Sismik Hız }(\mathrm{V} p) \\
(\mathrm{m} / \mathrm{s})\end{array}$ & 6155.56 & 6474.19 & 6373 & 108 \\
\hline $\begin{array}{c}\text { Schmidt } \\
\text { Sertliği (N tipi) }\end{array}$ & 28 & 47 & 35.8 & 6.3 \\
\hline $\begin{array}{c}\text { Schmidt } \\
\text { Sertliği (L tipi) }\end{array}$ & 26 & 38 & 31.1 & 4.07 \\
\hline Shore Sertliği & 54 & 70 & 61.2 & 4.38 \\
\hline $\begin{array}{c}\text { Görünür } \\
\text { Porozite (\%) }\end{array}$ & 0.17 & 0.33 & 0.25 & 0.06 \\
\hline $\begin{array}{c}\text { Toplam } \\
\text { Porozite (\%) }\end{array}$ & 0.18 & 0.41 & 0.26 & 0.33 \\
\hline $\begin{array}{c}\text { Tek Eksenli } \\
\text { Basınç Dayanımı } \\
\left(\sigma_{c}\right),(\mathrm{MPa})\end{array}$ & 57.32 & 97.86 & 72.91 & 16.72 \\
\hline $\begin{array}{l}\text { Endirek Çekme } \\
\text { Dayanımı }\left(\sigma_{t}\right), \\
(\mathrm{MPa})\end{array}$ & 6.27 & 8.3 & 7.61 & 0.73 \\
\hline $\begin{array}{c}\text { Nokta Yük } \\
\text { Dayanımı }\left(I_{s(50))}\right. \\
(\mathrm{MPa})\end{array}$ & 4.19 & 5.88 & 5.38 & 0.81 \\
\hline
\end{tabular}

Tablo 2. 2 nolu ocak sahasının fiziko-mekanik özellikleri [12]

\begin{tabular}{|c|c|c|c|c|}
\hline & \multicolumn{4}{|c|}{2 NOLU OCAK } \\
\hline & $\begin{array}{l}\text { Minimum } \\
\text { Değer }\end{array}$ & $\begin{array}{l}\text { Maksimum } \\
\text { Değer }\end{array}$ & $\begin{array}{l}\text { Ort. } \\
\text { Değer }\end{array}$ & $\begin{array}{c}\text { Standart } \\
\text { Sapma }\end{array}$ \\
\hline $\begin{array}{c}\text { Birim } \\
\text { Hacim } \\
\text { Ağırlık }\left(\mathrm{d}_{\mathrm{h}}\right) \\
\left(\mathrm{g} / \mathrm{cm}^{3}\right)\end{array}$ & 2.66 & 2.7 & 2.68 & 0.02 \\
\hline $\begin{array}{c}\text { Ağırlıkça } \\
\text { Su } \\
\text { Emme } \\
\text { (ASE), (\%) }\end{array}$ & 0.1 & 0.22 & 0.15 & 0.05 \\
\hline $\begin{array}{c}\text { Hacimce } \\
\text { Su } \\
\text { Emme } \\
\text { (HSE), (\%) }\end{array}$ & 0.23 & 0.33 & 0.28 & 0.14 \\
\hline $\begin{array}{c}\text { Gerçek } \\
\text { Yoğunluk } \\
\left(\mathrm{d}_{0}\right) \\
\left(\mathrm{kN} / \mathrm{m}^{3}\right) \\
\end{array}$ & 26.17 & 26.52 & 26.39 & 0.22 \\
\hline $\begin{array}{l}\text { Sismik Hız } \\
(\mathrm{V} p),(\mathrm{m} / \mathrm{s})\end{array}$ & 5777.33 & 6123.46 & 5975 & 132 \\
\hline $\begin{array}{l}\text { Schmidt } \\
\text { Sertliği } \\
\text { (N tipi) }\end{array}$ & 31 & 39 & 34.1 & 2.38 \\
\hline $\begin{array}{c}\text { Schmidt } \\
\text { Sertliği } \\
\text { (L tipi) }\end{array}$ & 26 & 37 & 30.8 & 3.88 \\
\hline $\begin{array}{l}\text { Shore } \\
\text { Sertligi } i\end{array}$ & 42 & 79 & 57.5 & 7.6 \\
\hline $\begin{array}{c}\text { Görünür } \\
\text { Porozite } \\
(\%)\end{array}$ & 0.23 & 0.33 & 0.28 & 0.14 \\
\hline $\begin{array}{c}\text { Toplam } \\
\text { Porozite } \\
(\%) \\
\end{array}$ & 0.26 & 0.37 & 0.3 & 0.06 \\
\hline $\begin{array}{c}\text { Tek Eksenli } \\
\text { Basınç } \\
\text { Dayanımı } \\
\left(\sigma_{c}\right),(\mathrm{MPa}) \\
\end{array}$ & 47.82 & 89.08 & 68.36 & 16.28 \\
\hline $\begin{array}{c}\text { Endirek } \\
\text { Çekme } \\
\text { Dayanımı } \\
\left(\sigma_{t}\right),(\mathrm{MPa}) \\
\end{array}$ & 6.47 & 8.05 & 7.29 & 0.65 \\
\hline $\begin{array}{c}\text { Nokta Yük } \\
\text { Dayanımı } \\
\text { ( Is(50)), } \\
(\mathrm{MPa})\end{array}$ & 3.92 & 5.77 & 4.56 & 0.84 \\
\hline
\end{tabular}

\section{Bulgular}

\subsection{Delme hızı analizi}

Ocaklarda gerçekleştirilen delik delme işlemlerinin $P R_{\text {Brüt ve }} P_{R_{N e t}}$ değerlerinin ortalamalarının makine çalışma parametreleri ile 1 nolu ocak sahası için nasıl değiştiği Tablo 3'te ve 2 nolu ocak sahası için nasıl değiștiği ise Tablo 4'de verilmiş olup, grafiksel olarak gösterimi ise 1 nolu ocak sahası için Şekil 6-7 ve 2 nolu ocak sahası için Șekil 8-9'da verilmiștir. 
Tablo 3. 1 nolu ocak sahası $P R_{\text {Brüt ve }} \mathrm{PR}_{\mathrm{Net}}$ değerleri [12]

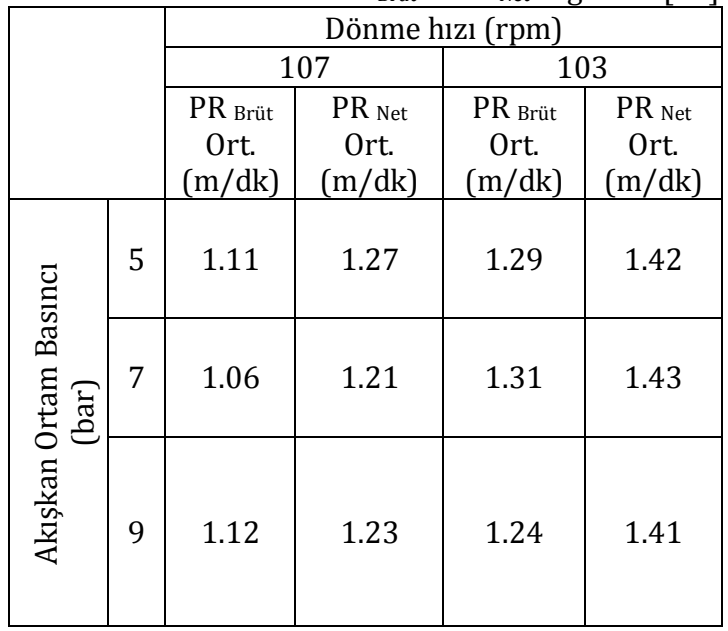

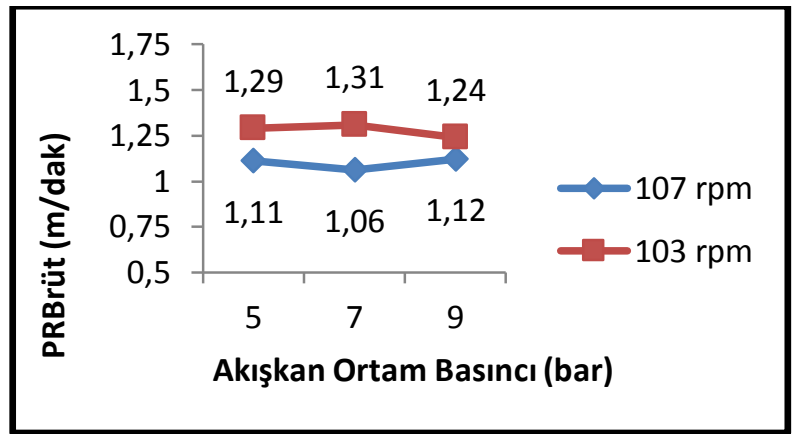

Şekil 6. 1 nolu ocağın makine çalıșma parametreleri ile $\mathrm{PR}_{\text {Brüt }}$ değerlerinin değișim grafiği [12]

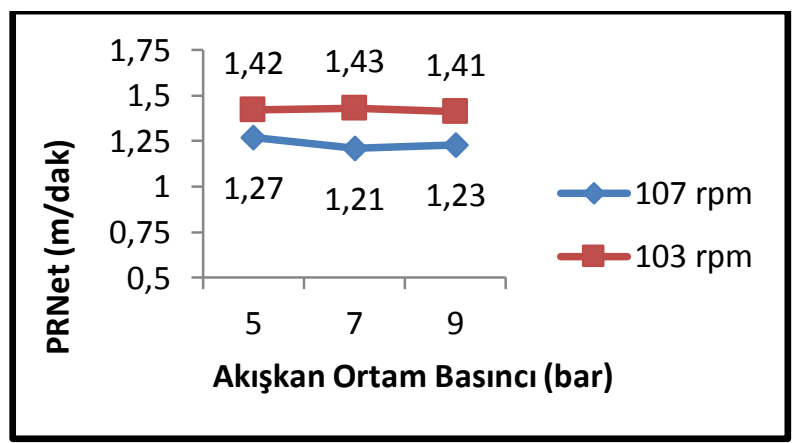

Şekil 7.1 nolu ocağın makine çalıșma parametreleri ile $\mathrm{PR}_{\text {Net }}$ değerlerinin değişim grafiği [12]

Tablo 4. 2 nolu ocak sahası PRBrüt ve PRNet değerleri [12]

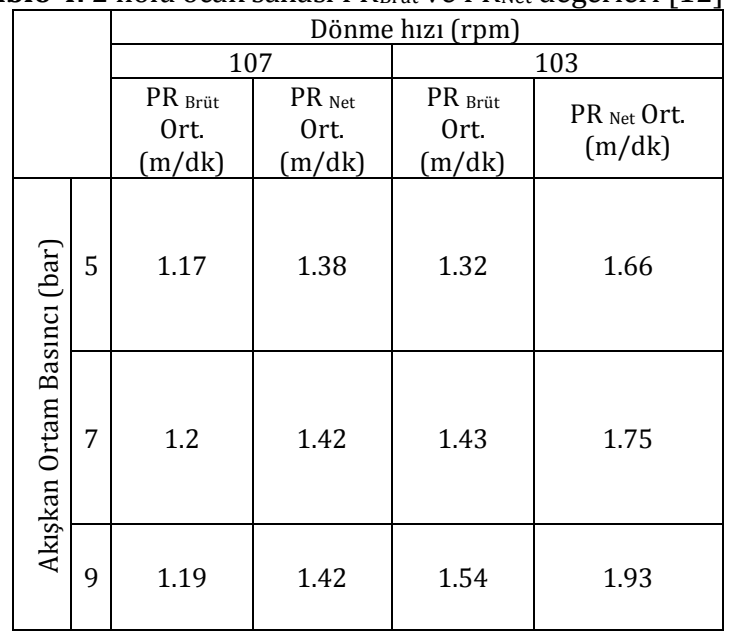

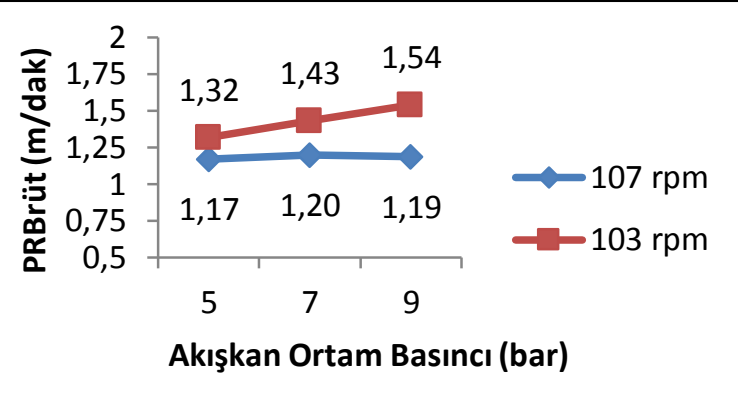

Şekil 8. 2 nolu ocağın makine çalışma parametreleri ile $\mathrm{PR}_{\text {Brüt değerlerinin değișim grafiği [12] }}$

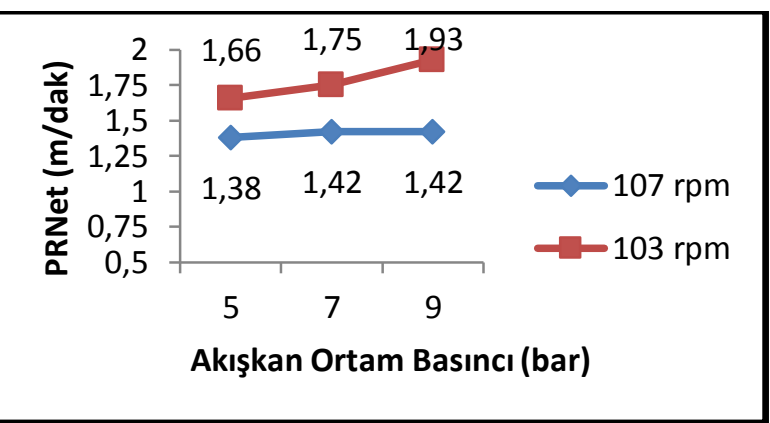

Şekil 9. 2 nolu ocağın makine çalışma parametreleri ile $\mathrm{PR}_{\mathrm{Net}}$ değerlerinin değișim grafiği [12]

\section{Tartışma ve Sonuç}

Delme işlemlerinde kullanılan delici makinelerin çalışma parametreleri ile delme hızı değerleri arasındaki ilişkinin ortaya konulması her zaman ilgi çeken bir araştırma konusu olmuştur.

1 ve 2 nolu ocak sahasında gerçekleştirilen delme işlemlerinde, delme hızlarının 103 rpm dönme hızındaki $P_{\text {net }}$ ve $P_{\text {brüt }}$ delik delme değerlerinin, 107 rpm dönme hızında ki $P_{\text {net }}$ ve $P_{\text {brüt delik delme }}$ hızlarından daha yüksek olduğu belirlenmiștir.

2 nolu ocak sahasının $\mathrm{PR}_{\text {net }}$ değerleri (Şekil 9) ve 1 nolu ocak sahasının $\mathrm{PR}_{\text {net }}$ (Şekil 7) incelendiği zaman, tüm akışkan ortam basıncı değerlerinde ve her iki dönme hızl değerinde de $\mathrm{PR}_{\text {net } 1<\mathrm{PR}_{\text {net} 2} \text { olduğu }}$ görülmektedir. Bu durum 2 nolu ocak sahasının 1 nolu ocak sahasına göre daha kolay delineceği sonucunu vermektedir.

$\mathrm{Bu}$ çalışmadan elde edilen verilerin araştırmacılara veri oluşturması açısından bir kaynak olacağı düşünülmektedir.

\section{Teşekkür}

Arazi çalışmalarımın gerçekleştirilmesinde katkılarından dolayı İrem Patlayıcı Mad. Doğ. Taş. Mad. Müh. Nak. İnş. Tur. San. ve Tic. Ltd. Şti. ile AKYAL İnş. Tic. ve San. Ltd. Şti. şirketlerine teşekkür ederim.

\section{Kaynakça}

[1] Koççaz, C.E., 2013. Göltaş (Isparta) Kireçtaşı Ocağında Darbeli Delme Performans Analizi ve 
Uygun Uç Seçimi, Süleyman Demirel Üniversitesi, Fen Bilimleri Enstitüsü, Isparta, Yüksek Lisans Tezi, 76.

[2] Çapik, M., 2014. Cankurtaran ve Salmankaş tünellerindeki kayaçların delinebilirlik, aşındırıcılık, mekanik ve petrografik özelliklerinin araștırılması, net delme hızı ve bit tüketimi ile ilişkilendirilmesi, Karadeniz Teknik Üniversitesi, Fen Bilimleri Enstitüsü, Trabzon, Doktora Tezi, 296.

[3] Yarall, O., ve Soyer, E., 2013 Assessment of relationships between drilling rate index and mechanical properties of rocks, Tunnelling and Underground Space Technology, 46-53.

[4] Ataei, M., KaKaie, R., Ghavidel, ve Saeidi. O., 2015. Drilling rate Prediction of an open pit mine using the rock mass drillability index, International Kournal of Rock Mechanics \& Mining Sciences, 130-138.

[5] 1 ve 2 nolu ocak sahasının genel görünümü. https://www.google.com/maps/@37.2326598, 29.6168572,2812m/data=!3m1!1e3 (Erişim Tarihi: 11.01.2019).

[6] Atlas Copco Flexi ROC T35 delici makine. https://www.epiroc.com/en-id/products/drillrigs/surface-drill-rigs/flexiroc-t35 $\quad$ (Erişim Tarihi: 11.01.2019).
[7] Özdemir, A., 2007. Kayaların delinebilirliğini etkileyen jeo-mühendislik özellikleri, Sondaj Dünyası Dergisi, 5, 15-18.

[8] Özdemir, A., 2011. Çambași regülatörü ve hes tünel güzergahındaki kayaların bazı mühendislik özellikleri ile delinebilirlikleri arasındaki ilișkinin incelenmesi, Gazi Üniversitesi, Fen Bilimleri Enstitüsü, Ankara, Yüksek Lisans Tezi, 248.

[9] TSE 13755, 2009. Doğal taşlar - Deney metotlarl- Atmosfer basincinda su emme tayini, TSE, Ankara.

[10] TSE 1936, 2010. Doğal taşlar - Deney yöntemleri- Gerçek yoğunluk, görünür yoğunluk, toplam ve açık gözeneklilik tayini, TSE, Ankara.

[11] ISRM (International Society for Rock Mechanics), 2007. Rock Characterization, Testing and Monitoring - ISRM Suggested Methods. E.T. Brown (ed.), Pergamon Press, 2011 p., Oxford.

[12] Tuncer, İ., 2018 Küçükalan Göleti ve Sulaması İnşaatı Kireçtaşı Ocağı Patlatma Deliği Delme Performans Etüdü, Süleyman Demirel Üniversitesi, Fen Bilimleri Enstitüsü, Isparta, Yüksek Lisans Tezi, 161. 